\title{
The Indonesian Grammatical Interference on EFL Students' Writing
}

\author{
Ayu Rizki Septiana \\ STKIP PGRI Tulungagung, Indonesia \\ ayu.rizki@stkiptulungagung.ac.id \\ *) correspondence: ayu.rizki@stkiptulungagung.ac.id
}

\begin{abstract}
This research was aimed to find out what factors of the occurrence of Indonesian grammar interference in EFL students' writing and what type of Indonesian grammar interference occur in EFL students' writing. To answer the research problem on Indonesian grammatical interference, a descriptive qualitative was done by taking the fourth semester students of English Department STKIP PGRI Tulungagung as the subject of the research. Further, the data related to the Indonesian grammar interference were taken using test and observation. The result of data analysis shows that the students still got interference from Indonesian grammar as their native language. The grammatical interference in this research is classified into two; syntactical interference and morphological interference. The syntactical interference consists of word order, preposition, extra word and missing word. The most interference in syntactical interference is on preposition. The morphological interference consists of omission of determiner, wrong determiner, subject-verb agreement, be form, tenses usage, singular and plural form. The most interference in morphological interference is omission of determiner. From the observation, it was found that the cause of interference is the different structure of Indonesian and English grammar. Moreover, the students usually wrote it first in Indonesian and later translated into English.
\end{abstract}

Keywords: Indonesian grammatical interference; EFL writing; L1 and L2 differences; descriptive qualitative

\section{INTRODUCTION}

Most of Indonesian does not use English in their daily communication since in Indonesia, English is known as foreign language. Instead, Indonesian people use their mother tongue or Indonesian as their national language to communicate. In school, for example, students use Indonesian to interact one to another. Even, it is very possible that in English subject, Indonesian is used as the media of communication. It is in line with Richards, et al.'s (2002) statement that foreign language is the language which is taught in school but it is not used in daily conversation.

Although English is not used in daily communication, it cannot be denied that English is needed in this era. The development of technology in this era demand people to use English frequently. As an impact English becomes compulsory subject for the secondary school. Pudiyono (2012) stated the result of English as a foreign language is unsuccessful. The use of mother tongue and any other first language cannot be denied to affect target language learning process (Ellis, 1986: 19). For example, Indonesian is often influenced by their first language in using English. Unfortunately, they often are not aware of the influences. Most of them think that understanding in communication is enough. It means that although the grammatical pattern is neglected, as long as the hearer can catch what the speakers say, that is enough (Martanti, 2011: 2). As an instance, when an Indonesian person says "Akusangatsukamembaca," they will say "I very like reading" instead of saying "I like reading very much." Because the language production is not grammatically acceptable, it will hard for other people understand what they are saying. The effect of first language toward the 
second language or vice versa can occur in different language system. The use of certain language system in other language is called transfer. Foreign language learners already have knowledge, pattern, and habit in using a language affected by their mother tongue or their first language. Therefore, it is difficult for them to learn a new pattern of foreign language. The earlier knowledge of language will have transferred to the target language. The transfer, further, can help foreign language learners to master the target language or even interfere the learners to master the target language.

Based on its nature, transfer in language learning can be divided into two. The first one is positive transfer. It can be happening when it is helpful for the language learners due to the similarity of the two languages. The second is negative transfer. Negative transfer can cause of confusion. It happens because the language learners adapt the system of a language that is actually different from the native language system. Negative transfer, further, is known as the language interference. Language interference often occurs in bilingual or multilingual countries. Errors may be found in many aspects such as phonology, morphology, and syntax or lexical and it may be occurred in writing and speaking.

As a result of the background stated above, the researcher is intended to find out whether Indonesian as the first language affects EFL students' writing. Since the goal of teaching writing in TEFL is to enable the students to produce written text as a media of communication, a research on writing and the interference related to the grammatical structure is very much needed. Further, the researcher wants to find out what the factors of the occurrence of Indonesian grammar interference in EFL students' writing and what type of Indonesian grammar interference occur in EFL students' writing.

In second language learning, some interference sometimes come up as the villain of the language learning. First language is often recognized as the interference in second language learning. According to Dulay, et al. (1982), there are two ways to describe what interference is. Psychological defines interference as the confusion that is influenced of the old habit in using first language when the new habit of second language comes. While the sociolinguistics defines interference as language interaction such as language borrowing and language switching that happens when two languages have interaction.

There are some types of interference in second language learning. Interference according to Weinrich (1959) can be divided into three:

1. The transfer of element from one language to another.

2. Application of elements that do not applicable to the second language into the first language.

3. Structure disobedience of second language because there is no equivalent in the first language.

In addition, Weinreich (1953) also divides interference forms into three parts; phonological interference, lexical interference, and grammatical interference. Grammatical interference occurs when second language learners apply the grammatical pattern, they learn in their first language to the target language. Grammatical interference can be identified in two kinds. First, the morphological interference is the interference that absorbs the affixes from other language.

Second, the syntactical interference is the syntactic of a language that is absorbed by other language. In Indonesian and English context, it is common to see the syntactical interference. For example, girl beautiful is the misplaced of beautiful girl since it is affected by the structure of Indonesian.

Considering the definitions of grammar and interference, grammatical interference also may occur in writing caused by the negative transfer of structures from first language, in this case Indonesian, to the target language. An analysis of error in students' writing can be one of the methods to know the grammatical interference in students' writing. Further, the grammatical interference in writing that is known by analyzing the errors will provide the information how the L2 learners learn the language and how much the L2 learners have learned (Shahin, 2011: 210). In this 


\section{Septiana, A., R.}

research, the researcher only focuses on analyzing the grammatical errors because of the interference of first language.

Some studies on L1 interference in students' writing have been made recently. Irmalia (2016) made a study on Indonesian interference in students' writing. The study found that students are commonly confused in using the right verb in tenses. Another study was done by Martanti (2011) who did a study on grammatical interference in articles of Berani Newspaper. The findings of this study showed that there are two kind of grammatical interference; morphological error and syntax error.

\section{METHODS}

The goal of this research was to find out whether Indonesian grammar interfere EFL students' writing, what causes of the grammatical interference, and what types of grammatical interference occur. The researcher tried to identify, classify, and describe the grammatical interference in the EFL students' writing.

The participant of this study was the fourth semester students who had taken Academic Writing course in academic year 2017/2018. They who officially registered in Academic Writing course were the subject of the study. According to Creswell (2012), sampling in qualitative research is purposeful sampling. In purposeful sampling, researcher intentionally selects individuals and sites to learn or understand the central phenomenon. The standard used in choosing participants and sites in whether they are "rich of information".

The setting of this research was the fourth semester students of English Department of STKIP PGRI Tulungagung. It is located in Mayor Sujadi Timur street number 7 Tulungagung. There were 22 students who were taken as the subjects of the research. The 22 students were those who were officially registered in Academic Writing course in academic year 2017/2018.

In conducting a qualitative research, there are two approaches that can be used (Berg, 2001). The first approach is theory- before-research. It means that in doing the research, the researcher starts from searching an idea, finding theory, deciding the research design, collecting data, analyzing the data and making conclusion. While the second approach is commonly known as researchbefore-theory. In this approach, after finding an idea for research, the researcher decides to design of the research. Further, the researcher collects the data, reviews the theory, analyzes the data and takes conclusion. In this research, the researcher took the first approach, that is, theory- beforeresearch.

After the data have been collected in three methods; the next step is analysis the data qualitatively. Here, the researcher first prepares the data on the Indonesian grammatical interference towards students' writing. Then, the data can be analyzed. Based on Berg (2001: 35), data analysis consists of three concurrent flows; data reduction, data display, and conclusion and verification.

\section{RESULTS AND DISCUSSION}

In this research, the researcher did analysis on the interference on the students' writing based on the notion of Suwito (1983) that classified the interference into two, syntactical and morphological interference. Yusuf (1994) stated that the main factor of interference is the difference between the source of language and target language. The differences usually occur in vocabulary and structure.

1.Syntactical interference

Syntactical interference said Suwito (1983), can be found in phrases, clauses and sentence. In thisresearch, the syntactical interference can be classified into word order, preposition, extra word and missing word. 
Table 1. SyntacticalInterference

\begin{tabular}{ccc}
\hline Kinds & Number & Percentage \\
\hline Word order & 8 & 18.6 \\
Preposition & 13 & 30.23 \\
Extra word & 10 & 23.26 \\
Missing word & 12 & 27.91 \\
\hline Total & 43 & $100 \%$
\end{tabular}

In the syntactical interference, the result of data analysis shows thatthere are 8 interferences on word order, 13 interference on preposition, 10 interference on extra word and 12 interference on missing word. Here, the most interference is on the preposition.

2. Morphological Interference

Morphological Interference occurs when the formation of words in a language absorb the affixes from otherlanguage(Suwito,1983).Inthis research, the morphological interference is classified into omission of determiner, wrong determiner, subject-verb agreement, be form, tenses usage, singular and plural form.

Table 2. Morphological Interference

\begin{tabular}{lll}
\hline Kinds & Number & $\begin{array}{l}\text { Percentag } \\
\mathrm{e}\end{array}$ \\
\hline $\begin{array}{l}\text { Omission of } \\
\text { Determiner }\end{array}$ & 23 & 28.06 \\
$\begin{array}{l}\text { Wrong } \\
\text { Determiner }\end{array}$ & 7 & 8.5 \\
$\begin{array}{l}\text { Subject-verb } \\
\text { Agreement }\end{array}$ & 12 & 14.63 \\
$\begin{array}{l}\text { Be form } \\
\text { Tenses usage }\end{array}$ & 11 & 18.29 \\
$\begin{array}{l}\text { Singular- } \\
\text { plural form }\end{array}$ & 14 & 13.43 \\
\hline Total & 82 & 17.09 \\
\hline
\end{tabular}

From the table above, it was found that there are 82 interference found in the students' writing. there are 23 interferences on omission of determiner, 7 interferences on wrong determiner, 12 interferences on subject-verb agreement, 15 interferences on be form, 11 interferences on tenses usage and 14 interferences on singular-plural form.

Observation was done during teaching and learning process. Since the researcher is also the teacher of the Academic Writing course, the observation was done when the researcher was teaching. Based on the result of the observation, it was found that the students still use Indonesian in the beginning of the writing. The students start to write by writing their very first idea in 


\section{Septiana, A., R.}

Indonesian. After that, they try to translate their writing into English. Therefore, they never start their process by thinking in English directly.

Besides, the students also found many difficulties with their vocabularies. They lack of vocabulary mastery so that they are difficult to write and find the appropriate vocabularies. Moreover, the students also have limited knowledge on grammar because they get interference from the Indonesian grammar which does not have any rules and structure like English grammar.

Language interference is a common thing in sociolinguistics especially in the multilingual community. It happens because of the differences between the source language and target language. In this research, the grammatical interference is classified into two, syntactical interference and morphological interference.

\section{SyntacticalInterference}

The syntactical interference is classified into four; word order, preposition, extrawordandmissingword.Thesyntactical interference exists in the form of phrase, clause, and bsentence.

a. Wordorder

The examples of interference on word order are asfollow:

... protect privacy people....

So, the censorship of film adult... The phrase privacy people should be people's, privacy. It is kind of interference from Indonesian since in Indonesian it can be translated into privasi orang. However, in English this structure does not exist. Instead, it should people's privacy. The next, thephrasefilmadultcanbetranslated into Indonesian as film dewasa. It violated the structure of English. The noun is film and the modifier isadult. In English, modifier usually comes before noun. So, it should adultfilm.

b. Preposition

The examples of interference on preposition are as follow:

It is same with... Different withthat opinion, I believe that.

The phrase same with should be written same as. The students actually wanted to write samadengan and they translated it into same with. Same is sama and with is dengan. However, the correct preposition after same is as. So, they got the interference of Indonesian in that phrase. The next phrase is different with. Again, it is because of the interference from Indonesian. Different with means berbeda dengan. So, they wanted to translate beda into different and dengan into with. Yet, they violate the structure of English since the correct preposition for different is from.

c. Extraword

d. The examples of interference on extra are as follow: And children can tocommunicate more polite with other people.

$\underline{\text { One form }}$ of film regulations is censorship.

In the first sentence, 'And children can to communicate more polite with other people', the extra word is to after can. After modal, it should be verb. So, the word 'to' should be omitted. In the second sentence, 'One form of film regulations is censorship', the word form should be omitted since the meaning would be the same if it is omitted.

e. Missingword

Missing word is the opposite of extra word in which some word should be added in order to have a correct meaning.Theexampleofinterference on missing word is asfollow:

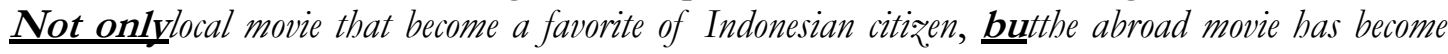
consumption for some citizen of Indonesia.

The phrase not only is always paired with the phrase but also. Here, the students only write but and they missed the word also.

\section{MorphologicalInterference}

Morphological interference is classifiedintoomissionofdeterminer, wrong determiner, subject- 
verb agreement, beform, tenses usage and singular-pluralform.

a. Omission ofdeterminer

The example of interference on omission of determiner is as follow:

Purpose of censoring film is to safe future generation.

Here, there should be a determiner 'the' in the sentence above. Although have the same meaning, but determiner can show the firm use ofa noun.

b. Wrongdeterminer

The example of interference on determiner is as follow:

I believe that censorship is needed on an film.

Here, the student wrote determiner an before word that does not start with a vocalletter. It may happen because an can be translated into sebuah in Indonesian while in Indonesian, there is no difference like in English between a and an.

c. Subject-verb agreement

It is a very common interference that can be found in students' writing. In Indonesian, there is no such thing. Therefore, it is very common if they write it wrongly. Forexample: But adult people who watches the movie.

The sentence above is wrong because adult people is plural and when they use simple present, they should write watch instead of watches.

d. Be form

There 3 reasons why censorship of film is important.

In the sentence above, the students missed the be form of are. It was written like in the sentence above because the student direct translated it from Indonesia 'ada tiga alasan mengapa mensensor film itupenting.

e. Ten sesusage

And the children must not to watching the film with adult content.

Here, the student used must which meansharus in Indonesian. However, it should be 'should'. So, the tense in the sentence should be 'and the children should not watch film with adult content.'

f. Singular and pluralform

In Indonesia, there is no difference in singularandpluralform.Yet, English has it differently. Commonly, we should add ' $s$ ' in the plural form. If the singular form is book, the plural form will be books. The examples of interference on singular and plural form are as follow:

Because of two reason about it...

Itwillmakesome negative impact...

In the example above, reason and impactshouldbeaddedwith's'because it is pluralform.

Based on the data above, it is proven that the students who take AcademicWriting course still get interference of Indonesian in writing. The most interference in syntactical interference is preposition. While in the morphological interference, the most interference is on omission of determiner. Thecauseofinterferenceinstudents'writing is the different structure between Indonesian and English.

\section{CONCLUSION}

This research was aimed atfinding out whether Indonesian grammatical interference on EFL students' writing causes of the interference and types of the interference occur in EFL students' writing. Based on the result of research findings and discussion in the previous chapter, it is proven that the students still get interference from Indonesian grammar as their native language. While for the cause of the interference, it is found that the different structure between Indonesian and English bring difficulties for the students to write so that they made many errors. Moreover, the students usually write first in Indonesian and later translate into English. The failure of the translation brings errors in the students' writing. 


\section{Septiana, A., R.}

The grammatical interference in students' writing is classified into two; syntactical and morphological interference. The syntactical interference consists of word order, preposition, extra word and missing word. The most interference in syntactical interference is on preposition. Further, the morphological interference consists of omission of determiner, wrong determiner, subject-verb agreement, be form, tenses usage, and singular and plural form. The most interference in morphological interference is on omission of determiner.

\section{ACKNOLEDGEMENTS}

I would like to address a deep gratitude to my institution that has already funded my research.

\section{REFERENCES}

Arikunto, S. (2010). Prosedur Penelitian. Suatu Pendekatan Praktek. Jakarta: RinekaCipta.

Ary, D., Lucy, C. J. \&Razavieh, A. (2010). Introduction to Research in Education (8 ${ }^{\text {th }}$ Edition). Belmont:Wadsworth.

Berg, B.L (2001). Qualitative Research Methods for the Social Sciences. California; Pearson Education.

Brown, H. D. (2001). Teaching by Principles an Interactive Approach to Language Pedagogy. New York: Pearson Education,Inc.

Chitravelu, N. (2007). ELT Methodology Principles \& Practice (second edition). Malaysia: Oxford Fajar.

Creswell John W. 2012. Research Design Edition Qualitative, Quantitave and Mixed Methods Approaches 4th Edition. London: Sage Publication.

Dulay, H., Burt, M., \& Krashen, S. (1982). Language Two. New York: Oxford UniversityPress.

Ellis, R. (1986). Understanding Second Language Acquisition. New York:Oxford UniversityPress.

Hedge,T.(2005).Writing. London: Oxford UniversityPress.

Hughes, A. (1989). Testing for Language Teachers. Melbourne: Cambridge. University Press.

Hyland, K. (2003). Second Language Writing. Cambridge: Cambridge University Press.

Irmalia, M. (2016). Indonesian Interference in Students' Writing. English Education Journal, 7 (4), 498 508. Retrieved fromhttp://www.jurnal.unsyiah.ac.id/EEJ/article/view/5535.

Lincoln, Y.S., \& Guba, E.G. (1985). Naturalistic Inquiry. Beverly Hills, CA: Sage.

Martanti, P. (2011). An analysis of grammatical interference in articles of Berani Newspaper. (Undergraduate thesis, Universitas Islam Negeri SyarifHidayatullah Jakarta, Jakarta,Indonesia). Retrieved fromrepository.uinjkt.ac.id.

Naidu, M. 2(007). The Use of Written Feedback and Conferencing in Improving Students' Writing. Retrieved from http://eprtp://kola.opus.hbz-nrw.de/volltexte/2008/271/

Oshima, A. \& Hogue, A. (2007). Introduction to Academic Writing (Third Edition). United States of America: Pearson Education Inc.

Pudiyono. (2012).Indonesian grammatical interference toward the students' spoken and written English. International Journal of Educational Studies, 4 (2), 229-244. Retrieved from http://www/educare-ijes.com/educarefiles/File/09.pudiyono.ump.pdf.

Richards,J.,Platt,J.,Weber,H., \& Inman, P. (2010). Longman Dictionary of Applied Linguistics. London:Pearson.

Septiana, A.R., Sulistyo, G.H.,Kadarisman, A.E. (2016). Corrective feedback and writingaccuracyacrossdifferentlevelsof grammatical sensitivity. Indonesian Journal of Applied Linguistics, 6 (1), 1- 11.http://dx.doi.org/10.17509/ijal.v6i1.2642

Shahin,N.(2011).Error Treatmentin TESOL Classroom. Jordan Journal of Applied Science: Humanities Series, 13 (1)., 207-226. Retrieved from http://www.asu.edu.jo/asu/userfiles/file/ HumanitiesSeries.pdf.

Suwito. (1983). Pengantar Awal Sosiolinguistik Teori dan Praktik. Surakarta: Henary Offset.

Weinrich, U. 1953. Language in Contact: Finding and Problems. New York: Mouton Publishers.

Yeasmin, S., \& Rahman, K.F. (2012). 'Triangulation' research methods as the tools of social science research. BUP Journal, 1 (1), 154-163.

Yule, G. (2010). The Study of Language (4th Edition). Cambridge: Cambridge University Press. 